\title{
A Critical Review of Acid Mine Drainage Treatment
}

\author{
Yudha Gusti Wibowo', Rahmat Fadhilah', Hutwan Syarifuddin², Anis Tatik \\ Maryani' ${ }^{2}$ Intan Andriani Putri ${ }^{3}$
}

${ }^{1}$ Department of Mining Engineering, Faculty of Technology and Production, Institut Teknologi Sumatera, Lampung, Indonesia

${ }^{2}$ Postgraduate Program of Environmental Science, Universitas Jambi, Jambi, Indonesia

${ }^{3}$ Department of Geophysical Engineering, Faculty of Technology and Production, Institut Teknologi

Sumatera, Lampung, Indonesia

*Corresponding author, e-mail: yudha.wibowo@ta.itera.ac.id

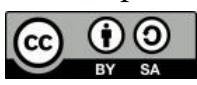

\begin{abstract}
Acid mine drainage has been reported to cause various environmental and human health problems. Acid mine drainage is formed due to the oxidation of sulfide minerals to water and air. This paper reports the efforts that have been made in the management and treatment of acid mine drainage. Thirty papers from reputable publishers are used as references. Efforts to prevent the formation of acid mine drainage can be made by making proper drainage and dewatering systems, making non-acid formations for rocks that have the potential to be oxidized. Active and passive treatment methods can be used to treat acid mine drainage. The active treatment method uses materials and chemicals to reduce pollutant parameters, while the passive method utilizes natural processes to reduce pollutant parameters in acid mine drainage. The combination of active and passive methods using novel materials that have been researched is recommended to produce the best system that can thoroughly remove pollutants in acid mine drainage.
\end{abstract}

Keywords: Acid mine drainage; acid mine drainage treatment; active treatment; passive treatment

\section{Introduction}

Acid mine drainage is one of the wastes generated from coal mining activities. Acid mine drainage is formed due to the oxidation of sulfide minerals in contact with water and air (Qureshi et al., 2016). The formation of acid mine drainage is widely studied worldwide because of the negative impact it has on the environment (Bwapwa et al., 2017; Skousen et al., 2017; Zhang, 2011). Pyrite, iron disulfide $(\mathrm{FeS} 2)$, is a rock commonly contaminated by water and air to produce acid mine drainage. The harmful impact caused by the formation of acid mine drainage is due to the low $\mathrm{pH}$ (as low as 4) and has the high content of heavy metals. Heavy metals usually associated with sulfide minerals are $\mathrm{Mn}, \mathrm{Fe}, \mathrm{Pb}, \mathrm{Hg}$, Cd. (Lewis, 2010). This heavy metal content is the factor that has the most potential to pollute the environment and cause health problems in humans (Järup, 2003).

Various studies have been reported as handling efforts to prevent the formation of acid mine drainage to treatment that can be carried out when acid mine drainage has formed (Kefeni et al., 2017; Skousen et al., 2017; Tabelin et al., 2018). Making drainage and dewatering systems is a method used to prevent the formation of acid mine drainage (Wibowo and Syarifuddin, 2018). On the other hand, nonacid formation in rock and overburden, which can produce acid mine drainage, is also recommended 
for use. The presence of sulfide minerals can cause the formation of acid mine drainage in mining activity areas as a source of sulfur (pyrite, marcasite, chalcocite, pyrrhotite, covellite, molybdenite, galena, chalcopyrite, sphalerite, and arsenopyrite), air and water as oxidation washing agents (Rambabu et al., 2020). In addition to prevention, efforts that can be taken to reduce the damage caused by acid mine drainage are processed.

In general, acid mine drainage treatment techniques are active and passive. However, this technique continues to be more specific by looking for the novelty of the material used in each method. In addition, the most widely used process at mining sites is the use of quicklime $\left(\mathrm{CaCO}_{3}\right)$, hydrated lime $\left(\mathrm{Ca}(\mathrm{OH})_{2}\right)$, soda-ash $\left(\mathrm{Na}_{2} \mathrm{CO}_{3}\right)$, or caustic soda $(\mathrm{NaOH})$. Active technology utilizes neutralization, aeration, and deposition processes. While passive acid mine drainage technology is not treated using any chemicals and only utilizes reactions formed through natural processes. Although various papers have informed the use of active and passive technologies, reviews of all technological developments used to reduce pollutant parameters in acid mine drainage are still infrequent. Several papers published in the last ten years only inform the treatment of acid mine drainage using one method.

This review is expected to provide complete information on the techniques and materials used to reduce pollutant parameters in acid mine drainage. This paper will also provide comprehensive information related to the formation of acid mine drainage, acid mine drainage problems in the world, prevention of acid mine drainage formation, types of acid mine drainage, materials developed for acid mine drainage, and the latest technologies and methods used to treat acid mine drainage. This paper uses a reputable journal indexed by Scopus so that the source used is reliable and accountable.

\section{Method}

The method used in this study is a review. The scientific articles (52 papers) used as reference sources in this research come from journals published by Publishers Elsevier, Springer, Nature, and other reputable international and national (Indonesian) journals. The keywords used to find scientific articles used as references are acid mine drainage, acid mine drainage treatment, acid mine drainage review, adoption of acid mine drainage, bioremediation of acid mine drainage.

\section{Result and Discussion}

\subsection{Acid Mine Drainage}

Mining activities will harm biogeophysical aspects. The impact can cause a decrease in the quality and quantity of surface and groundwater (RoyChowdhury et al., 2015). The reduction in water quantity can be in the form of a reduction in the groundwater level or river discharge, while a reduction of water quality in the form of an increase in turbidity and an increase in chemical pollutant parameters (heavy metals). Mining activities carried out by clearing land widely and profoundly will accelerate the formation of acid mine drainage. The opening of topsoil will cause the pyrite mineral to be exposed to the environment. Pyrite minerals that are tightly packed with air and water are the source of the formation of acid mine drainage. The reaction resulting from the construction of acid mine drainage follows equation 1-4.

$$
\begin{aligned}
& \mathrm{FeS}_{2}+7 / 2 \mathrm{O}_{2}+\mathrm{H}_{2} \mathrm{O}<==>\mathrm{Fe}^{2+}+2 \mathrm{SO}_{4}{ }^{2-}+2 \mathrm{H}^{+} \\
& \mathrm{Fe}^{2+}+1 / 4 \mathrm{O}_{2}+\mathrm{H}^{+}<==>\mathrm{Fe}^{3+}+1 / 2 \mathrm{H}_{2} \mathrm{O} \\
& \mathrm{Fe}^{3+}+3 \mathrm{H}_{2} \mathrm{O}<==>\mathrm{Fe}(\mathrm{OH})_{3}+3 \mathrm{H}^{+} \\
& \mathrm{FeS}_{2}+14 \mathrm{Fe}^{3+}+8 \mathrm{H}_{2} \mathrm{O}<==>15 \mathrm{Fe}^{2+}+2 \mathrm{SO}_{4}^{2-}+16 \mathrm{H}^{+}
\end{aligned}
$$


In Eq. (1), iron sulfide is oxidized to produce ferrous iron $\left(\mathrm{Fe}^{2+}\right)$, sulfate $\left(\mathrm{SO}_{4}^{2-}\right)$ dan acid (ion $\mathrm{H}^{+}$). Ferrous iron can then be oxidized to form ferrous iron (Fe3+), as shown by Eq. (2). Furthermore, ferric iron is hydrolyzed to ferric hydroxide $(\mathrm{FeOH})_{3}$ and ion $\mathrm{H}^{+}$(Eq. 3). Acidity $\left(\mathrm{H}^{+}\right)$formed can act as a catalyst in breaking down pyrite $\left(\mathrm{FeS}_{2}\right)$ produce more ferrous ions (Fe2+), sulfate, and $\mathrm{H}+$ (reaction equation 4). If the reaction shown in the above equation slows down or stops, acid mine drainage formation will also slow down. A decrease in the intensity of water, air or pyrite rock can cause acid mine drainage to form more slowly than it should. Likewise, the more volumes of pyrite rock, water, and air in contact, the faster the formation of acid mine drainage (Said, 2014).

Many pyrite rocks are found under the water table. These locations usually have very little oxygen content, preventing acid mine drainage from forming. Under controlled conditions, oxygen conditions are limited, that very little water is oxidized. This condition will also disappear when there is dilution below the surface caused by dilution caused by soil infiltration or because alkaline rocks below the surface neutralize it. Different conditions will be found if the pyrite rock is disturbed due to land clearing. The pyrite rock will contact oxygen, surface water, and rain, resulting in acid mine drainage. Eq 2 will last until the oxidation of pyrite minerals. This reaction occurs due to the conversion of ferrous ions into ferrous in abiotic conditions ( $\mathrm{pH}$ less than 5 in abiotic conditions). Eq 2 can be accelerated in the presence of iron-oxidizing bacteria (Thiobacillus) (Wood et al., 2001). The mechanism of pyrite mineral oxidation can be seen in Fig. 1.

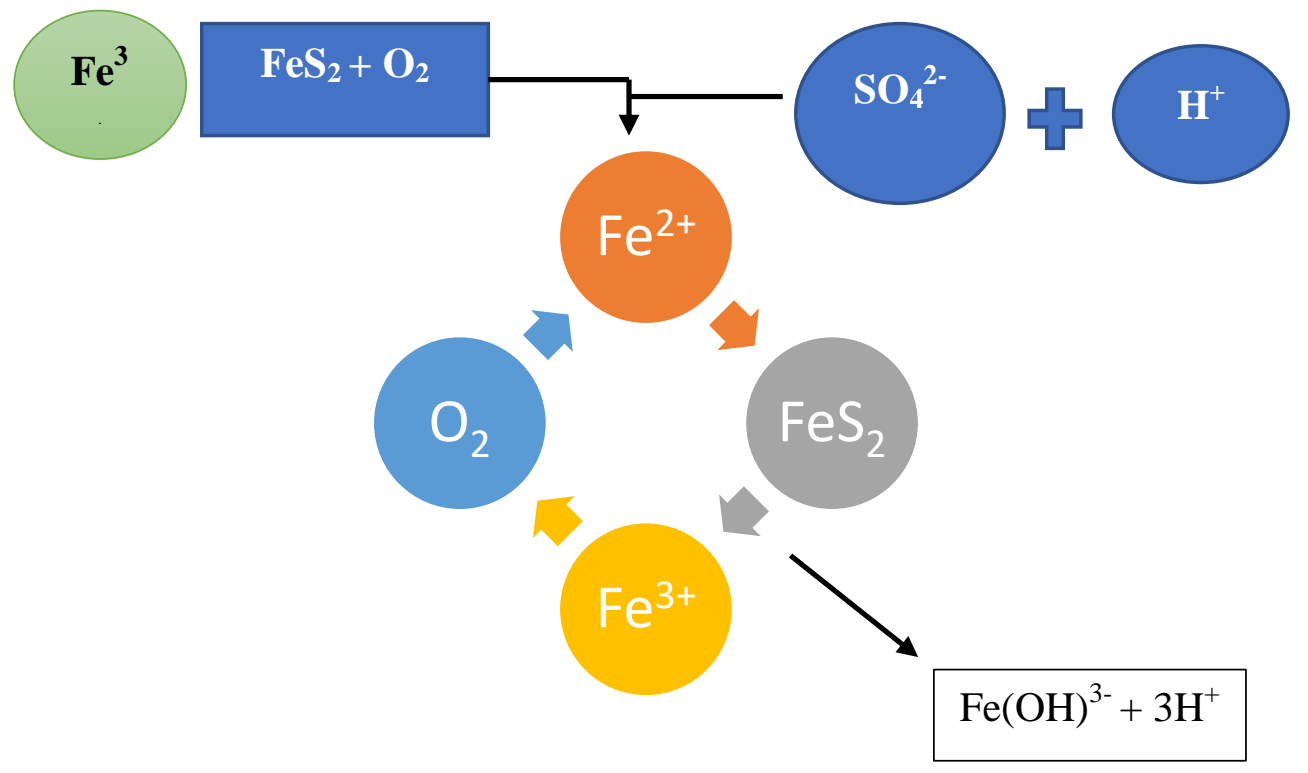

Figure 1. Pyrite oxidation

\subsection{Worldwide Acid Mine Drainage Problems}

Over a century, mining has become a crucial sector in South Africa. The impact of mining activities carried out for a long time has been recorded to produce acid mine drainage in several provinces such as Gauteng, Mpumalanga, North West, and the Free State (Naidoo, 2015). Although South Africa has implemented several laws to reduce environmental pollution caused by acid mine drainage, the expected results are still not optimal. A site in Gold Reef City has been reported to be polluting the environment with a hazardous status. In 2012, South African media reported anticipating acid mine drainage's impacts on the Vaal River system. The South African government has reportedly agreed to conduct an emergency response to acid mine drainage. The government is willing to pump acid mine drainage from various pollutant sources and neutralize the acid mine drainage (Naidoo, 2015). Another study stated that South Africa had experienced severe acid mine drainage pollution caused by mining at the Witwatersrand Goldfield. This mining activity worsens surface water quality 
because it is directly connected to water flows such as lakes and rivers. In this area, several characteristics of acid mine drainage were found that could degrade environmental quality, such as low $\mathrm{pH}, \mathrm{SO}_{42-}$, $\mathrm{Fe}, \mathrm{Al}, \mathrm{Co}, \mathrm{Cu}, \mathrm{Mn}, \mathrm{Ni}, \mathrm{U}$, and $\mathrm{Zn}$. (Tutu et al., 2008).

A recent study informed that acid mine drainage impacted water quality, stream sediment and periphytic diatoms. Stream sediment samples were taken at several locations such as the Roxo stream (sites B, Roxo; C, Porto Ferreira; and D, Jungeiros), one in gua Azeda stream (site E, gua Azeda), and four in gua Forte stream (site A, guas Industriais Dam-upstream from the mine; F, gua Forte; G, Ponte do Curval; and H, Porto de Beja), while water samples were taken at two different seasons. Epilithic samples were obtained by scraping five boulders using a toothbrush and epiphytes by squeezing the plant from the river margin. The results showed that the sediment stream contains $\mathrm{Al}, \mathrm{As}, \mathrm{Ca}, \mathrm{Cd}, \mathrm{Cu}$, $\mathrm{Fe}, \mathrm{K}, \mathrm{Mn}, \mathrm{Na}, \mathrm{Ni}, \mathrm{Pb}, \mathrm{S}, \mathrm{Sb}$ and $\mathrm{Zn}$. In addition, water samples in the area are known to contain As, 1.7-

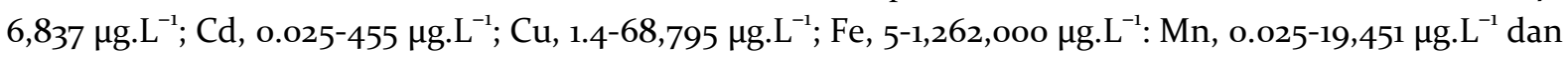
$\mathrm{Pb}, 0.05^{-136} \mu \mathrm{g} . \mathrm{L}^{-1}$ (Luís et al., 2009).

Another study informed that acid mine drainage was contaminated the Amous River, France. Over five years, dissolved and particulate was found in this river, including $\mathrm{Pb} . \mathrm{Tl}, \mathrm{Cd}, \mathrm{Zn}, \mathrm{Ni}, \mathrm{Cu}, \mathrm{Mn}$, $\mathrm{Co}, \mathrm{Fe}$ and $\mathrm{Al}$ with $\mathrm{pH}$ range is 6.5-8.8 (Casiot et al., 2009). $\mathrm{n}$ general, all areas that use the open-pit mining method will produce acid mine drainage. Characteristic differences in pollutant parameters found in each region are caused by the geological conditions of the area and the geochemical processes that occur. Geochemical engineering and efforts to protect the potential acid formation from oxidation are essential. Making non-potential acid formation is mandatory for all mining activities in the world. Avoiding water and air contamination of sulfide minerals can reduce the potential for acid mine drainage. Prevention will not only have a good impact on the environment but can also reduce environmental management costs. It is not known the exact charges that a company must incur to remediate acid mine drainage. There is no practical method to reduce all pollutant parameters in acid mine drainage.

In various regions of the world, mining activities (especially coal) are always in remote areas and far from the provincial capital. This condition is one of the factors that cause a lot of surface water and groundwater pollution caused by mining activities. The lack of supervision due to the long-distance and difficulty of travelling is used by rogue companies that do not adequately carry out environmental management. In addition, the high cost of environmental management is also one of the reasons why companies often do not manage their environment correctly. Other factors also affect the low awareness of mining workers that the absence of environmental management will have a terrible longterm impact on the environment and human life. How far and how long the lousy effect will last.

Sustainable management and technology are needed to reduce mining activities' negative impacts. Mining techniques that prioritize sustainability include three essential aspects, namely economic, social and environmental. Mining activities must improve the community's economy around the mining area. On the other hand, mining activities must be able to positively impact the community's social life and not damage the environment. These aspects must go hand in hand to create a sustainable mine management system. Research informs how to do sustainable mining starts from good waste management. The study analyzed mining waste and its sustainability from 1988 to 2017 . Based on 59 papers from reputable international journals, efforts that must be made to reduce the problem of surface water pollution are to increase the low $\mathrm{pH}$ of the water and maintain ecological stability (Aznar-Sánchez et al., 2018). The acid mine drainage contamination worldwide can be seen in Table 1. 
Table 1. Worldwide acid mine drainage problems

\begin{tabular}{|c|c|c|c|c|}
\hline No & Location/Country & $\mathbf{p H}$ & Parameters & Reference \\
\hline 1 & Indonesia & 3.93 & $\mathrm{Fe}, \mathrm{Mn}, \mathrm{Al}$ & (Nasir et al., 2013) \\
\hline 2 & $\begin{array}{l}\text { Nort Sulawesi, } \\
\text { Indonesia }\end{array}$ & - & $\mathrm{Hg}$ & (Lasut and Yasuda, 2010) \\
\hline 3 & US State & 1 & $\mathrm{Fe}(\mathrm{III})$ & (To et al., 1999) \\
\hline 4 & Nort Sulawesi & - & As & (Poedjiratrajoe, 2012) \\
\hline 5 & Spain & - & $\mathrm{Fe}$ & (Gibert et al., 2013) \\
\hline 6 & $\begin{array}{l}\text { Weel Jane, United } \\
\text { Kingdom }\end{array}$ & $<4$ & $\mathrm{Zn}, \mathrm{Cu}, \mathrm{Cd}, \mathrm{Fe}, \mathrm{Ar}$ & $\begin{array}{l}\text { (Whitehead and Prior, } \\
\text { 2005) }\end{array}$ \\
\hline 7 & South Africa & $2-8.5$ & $\begin{array}{l}\mathrm{SO}_{4}{ }^{2-}, \mathrm{NO}_{3}^{-}, \mathrm{Cl}^{-}, \mathrm{Al}, \mathrm{Cu}, \mathrm{Co}, \\
\mathrm{Fe}, \mathrm{Mn}, \mathrm{Ii}, \mathrm{Zn}, \mathrm{U}\end{array}$ & (Tutu et al., 2008) \\
\hline 8 & Batch sorption in Lab & $2-6.8$ & $\mathrm{SO}_{4}^{2-}$ & (Neculita et al., 2007) \\
\hline 9 & No information & - & $\begin{array}{l}\mathrm{Pb}^{2+}, \mathrm{Cu}^{2+}, \mathrm{Ni}^{2+}, \mathrm{Zn}^{2+}, \mathrm{Cr}^{6+} \text {, } \\
\text { and } \mathrm{Cd}^{2+}\end{array}$ & (Wei et al., 2019) \\
\hline 10 & Yatani mine, Japan & $2.9-8.9$ & $\begin{array}{l}\mathrm{Na}, \mathrm{K}, \mathrm{Cl}, \mathrm{Mg}, \mathrm{Ca}, \mathrm{HCOO}, \\
\mathrm{SO}_{4},\end{array}$ & (Tomiyama et al., 2019) \\
\hline 11 & $\begin{array}{l}\text { Shandong Province, } \\
\text { China }\end{array}$ & - & $\mathrm{Pb}(\mathrm{II}), \mathrm{Cu},(\mathrm{II}), \mathrm{Zn}(\mathrm{II})$ & (Zhang, 2011) \\
\hline 12 & $\begin{array}{l}\text { Turkey (Artificial } \\
\text { solution) }\end{array}$ & - & $\mathrm{Fe}, \mathrm{Cu}, \mathrm{Mn}$ and $\mathrm{Zn}$ & (Motsi et al., 2009) \\
\hline 13 & Amous River, France & $2.8-8.4$ & $\mathrm{HCO}^{3-}, \mathrm{SO}_{4}{ }^{2-}, \mathrm{DOC}, \mathrm{Cl}^{-}$ & (Casiot et al., 2009) \\
\hline 14 & $\begin{array}{l}\text { No information } \\
\text { (review) }\end{array}$ & - & $\begin{array}{l}\mathrm{Mn}, \mathrm{Fe}, \mathrm{Zn}, \mathrm{Pb}, \mathrm{Cu}, \mathrm{SO}_{4}, \mathrm{Co} \\
\mathrm{Ni}\end{array}$ & (Bwapwa et al., 2017) \\
\hline 15 & Guangdong, China & - & $\mathrm{Pb}, \mathrm{As}, \mathrm{Zn}, \mathrm{Cu}, \mathrm{Cd}$ & (Liao et al., 2016) \\
\hline 16 & Artificial solution & - & $\mathrm{Fe}$ & (Alegbe et al., 2019) \\
\hline 17 & $\begin{array}{l}\text { abandoned mine, } \\
\text { Kentucky-West } \\
\text { Virginia border }\end{array}$ & - & $\begin{array}{l}\mathrm{Al}, \mathrm{Sb}, \mathrm{As}, \mathrm{Ba}, \mathrm{Be}, \mathrm{Cd}, \mathrm{Cr}, \mathrm{Co} \text {, } \\
\mathrm{Cu}, \mathrm{Fe}, \mathrm{Pb}, \mathrm{Mg}, \mathrm{Mn}, \mathrm{Se}, \mathrm{Sr}\end{array}$ & (Matlock et al., 2002) \\
\hline 18 & $\begin{array}{l}\text { River Murray (South } \\
\text { Australia) }\end{array}$ & & $\begin{array}{l}\text { Acidity, Alkalinity } \mathrm{Al}, \mathrm{Ca}, \mathrm{Cl} \text {, } \\
\text { DOC, } \mathrm{Fe}, \mathrm{K}, \mathrm{Mg}, \mathrm{Mn}, \mathrm{Na}, \mathrm{N}\end{array}$ & (Mosley et al., 2015) \\
\hline 19 & $\begin{array}{l}\text { West Sumatera, } \\
\text { Indonesia }\end{array}$ & & $\mathrm{pH}, \mathrm{TSS}, \mathrm{Fe}$ and $\mathrm{Mn}$ & (Sari et al., 2020) \\
\hline 20 & Artificial solution & & Fe and $\mathrm{Mn}$ & (Wibowo et al., 2020) \\
\hline
\end{tabular}

\subsection{Acid Mine Drainage Treatment}

Acid mine drainage treatments are generally divided into active and passive treatment (Rakotonimaro et al., 2017). Acid mine drainage treatment with a dynamic method utilizes alkaline chemicals to increase the water's $\mathrm{pH}$ and precipitate metals. The active approach is more effective than the passive method, but this method has a higher cost than the passive method. The high price of the operational process is due to the purchase of alkaline materials and labour costs. Acid mine drainage treatment with active methods generally utilizes $\mathrm{CaO}$ to form $\mathrm{Ca}(\mathrm{OH})_{2}$ so that the $\mathrm{pH}$ of the water can increase (Skousen et al., 2019). The variables considered in the active treatment method for acid mine drainage are $\mathrm{pH}$, water discharge, TSS, heavy metal concentration, distance from treatment points and river water bodies. 
Acid mine drainage treatment passively utilizes the wetlands system and other natural processes (Sheoran and Sheoran, 2006). Passive methods are rarely used and are less effective in reducing pollutant parameters in acid mine drainage. The low ability of passive treatment is caused by the absence of additional materials that can accelerate reducing pollutant parameters in acid mine drainage. Passive treatment methods usually utilize swamps (artificial or natural) planted with Typha and other swamp plants with a depth of $<30 \mathrm{~cm}$ (Skousen et al., 2017). The impermeable sediment used in this method consists of clay and mine spoil. This method is expected to produce FeOOH deposits derived from $\mathrm{Fe}^{2+}$ found in acid mine drainage. Aerobic land use is expected to reduce the Fe content in acid mine drainage. The decrease in Fe content is due to proton formation by Fe hydrolysis following Eq 5 .

$\mathrm{Fe}^{3+}+3 \mathrm{H}_{2} \mathrm{O}<==>\mathrm{Fe}(\mathrm{OH})_{3}+3 \mathrm{H}^{+}$

In addition to the artificial aerobic land system, the anaerobic land system can also be used as a passive treatment for acid mine drainage (Demchak et al., 2001). Anaerobic modified land is intended to increase $\mathrm{pH}$ in acid mine drainage; increasing $\mathrm{pH}$ is expected to precipitate heavy metals (precipitation). The anaerobic land method is carried out by adding quicklime or limestone under an organic substrate. This technique will produce $\mathrm{HCO}_{3} . \mathrm{HCO}_{3}$ will neutralize the $\mathrm{pH}$ of the acid mine drainage according to Eq. 6 to Eq. 8.

${ }_{2} \mathrm{CH}_{2} \mathrm{O}+\mathrm{SO}_{4}{ }^{2-} \rightarrow \mathrm{H}_{2} \mathrm{~S}+2 \mathrm{HCO}_{3}$
$\mathrm{CaCO}_{3}+\mathrm{H}^{+} \rightarrow \mathrm{Ca}^{2+}+\mathrm{HCO}_{3}$
$\mathrm{HCO}_{3}^{-}+\mathrm{H}^{+} \rightarrow \mathrm{H}_{2} \mathrm{O}+\mathrm{CO}_{2 \text { (aq) }}$

The use of wetlands is one of the preferred methods for reducing pollutant parameters in acid mine drainage. Unfortunately, the use of this method has drawbacks, such as requiring large areas of land for processing acid mine drainage by nature. Extensive use of wetlands will increase environmental management costs. Another effort that can be made to reduce the area of wetlands used in the passive treatment method is to make anoxic limestone channels. This channel is made like drainage filled using limestone to neutralize the $\mathrm{pH}$ of the acid mine drainage (Eq. 9). Acids formed from limestone will also rapidly produce bicarbonate alkalinity (Eq. 7). Anoxic limestone ducts are usually lined with mud to avoid contact between acid mine drainage and air. The effluent produced in this process must be accommodated in a separate settling pond. This separation aims to prevent blockage in the channel caused by heavy metals' precipitation in acid mine drainage. Calcite and dolomite were used in anoxic limestone drains. The study results informed that the equilibrium point for the use of calcite and dolomite in increasing the $\mathrm{pH}$ of acid mine drainage was at 20 hours. The results of the study informed that the equilibrium point for the use of calcite and dolomite in increasing the $\mathrm{pH}$ of acid mine drainage was at 20 hours. The results of this study also inform that the higher the dose of calcite or dolomite used, the faster the $\mathrm{pH}$ will increase in acid mine drainage (Genty et al., 2012).

$\mathrm{CaO}+\mathrm{H}_{2} \mathrm{O} \rightarrow \mathrm{Ca}(\mathrm{OH})_{2}$

The third passive treatment method to minimize pollution caused by acid mine drainage is the vertical flow system method. This method is a combination of wetlands and anoxic limestone drains methods. The thing that should be of concern in this method is the activity of aerobic bacteria on the organic layer that captures dissolved oxygen. This process reduces the organic content in the organic layer and limestone. Aerobic bacteria in this method will produce alkaline conditions to increase the $\mathrm{pH}$ of acid mine drainage. Management of acid mine drainage by passive treatment must consider several variables such as acidity level of acid mine drainage $(\mathrm{pH})$, heavy metal concentration $(\mathrm{mg} / \mathrm{L})$, redox conditions, and sulfate concentration. Overall, the schematic diagram of acid mine drainage treatments can be seen in Fig. 2. 

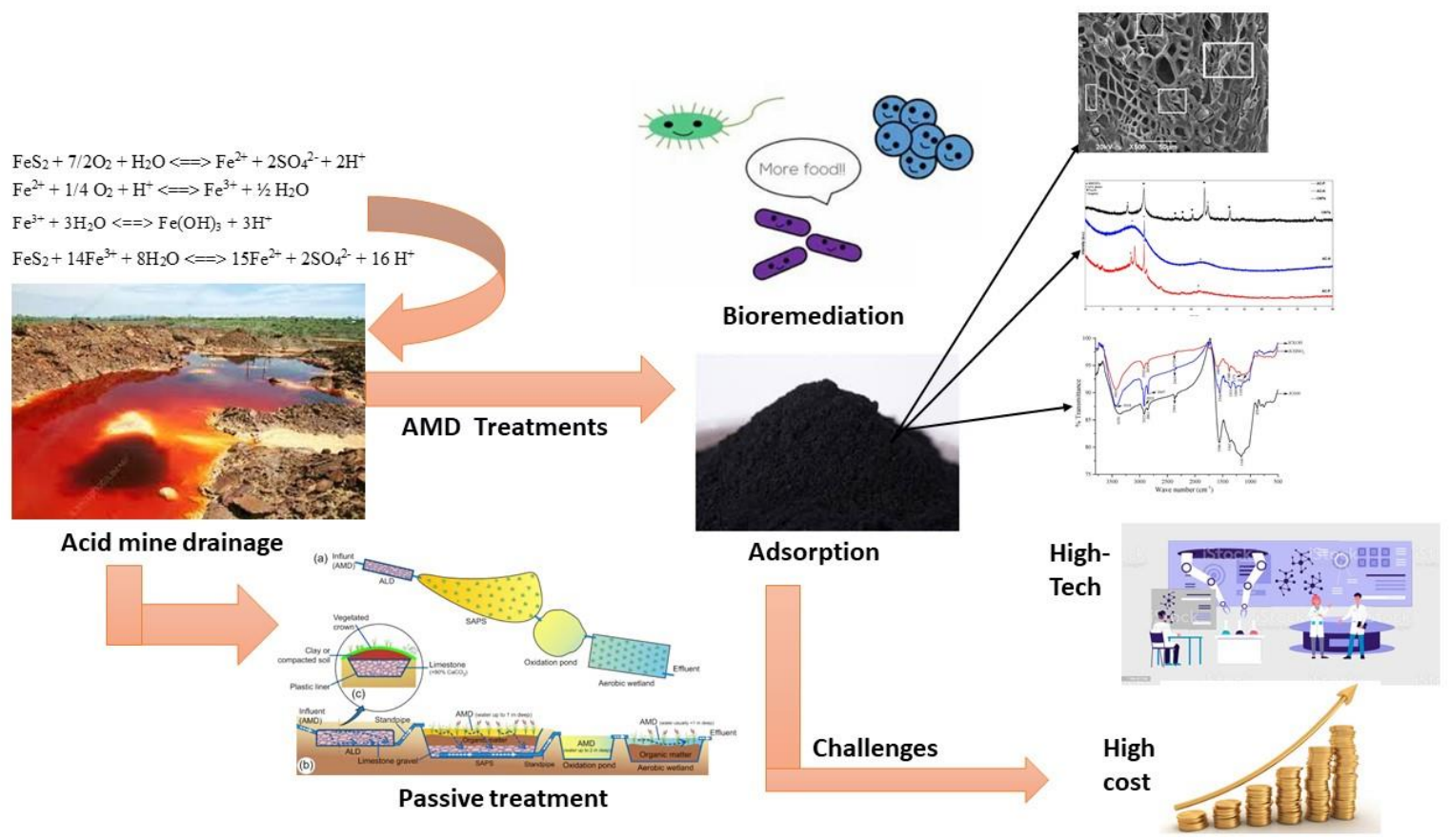

Figure 2. Schematicproblem, solution and challenge of acid mine drainage treatments

\subsection{Recent Technologies of Acid Mine Drainage Treatment}

Open-pit mining activities will cause wide and deep land openings. This condition will make it easier for sulfide minerals to oxid by air and water. The oxidation of sulfide minerals to water and oxygen will cause acid water conditions. This condition will also increase the mobilization of heavy metals in the water. High metal mobilization will cause metal concentration in water to increase under acidic conditions. Various studies have been carried out to reduce the pollutant content in acid mine drainage. More than 50 pages are found on Google Scholar to find the articles using the keyword acid mine drainage treatment. This result informs that the problem of acid mine drainage has become the focus of research by various researchers worldwide. Despite decades of research, there are still many problems related to acid mine drainage in various countries. This condition seems to inform that acid mine drainage is still an environmental problem and an unresolved issue. Even the latest research in 2021 informs the acid mine drainage problem that has not been completed. The bioremediation method is used in wetlands microcosms using organic substrates and supplementing domestic wastewater and plant litter broth. The research informs that Gravel-based subsurface-flow constructed wetlands. This method successfully reduced the heavy metal content in acid mine drainage (except $\mathrm{Fe}$ and $\mathrm{Cr}$ ) without adding carbon material (Chen et al., 2021). However, it succeeded in reducing the content of other heavy metals. Unfortunately, the method developed was not able to reduce the content of $\mathrm{Fe}$ and $\mathrm{Cr}$. Fe is one of the heavy metals most commonly found in acid mine drainage. Fe is also known to be very harmful to the environment and human health. In addition to $\mathrm{Fe}, \mathrm{Cr}$, which has not been successfully degraded, is also one of the heavy metals which is very toxic and harmful to the environment and human health. A study even found plants that have been contaminated with Fe so it is hazardous for human health. The plant samples were taken from the abandoned mine in Rosalgar (Setúbal District, SW Portugal). Besides Fe the plants were also known to contain high levels of Mn. The content of Fe and $\mathrm{Mn}$ in these plants is the impact of soil pollution that occurred in the abandoned mine in Rosalgar area (Sabina et al., 2019).

A study in China informed that the content of $\mathrm{Pb}(\mathrm{II}), \mathrm{Cu}(\mathrm{II})$, and $\mathrm{Zn}(\mathrm{II})$ can be reduced by using the adsorption method using dairy manure compost material. The adsorption capacity of each chicken manure compost material is $\mathrm{Pb} 0.428 \mathrm{mmol} / \mathrm{g}$, Fe $0.460 \mathrm{mmol} / \mathrm{g}$, $\mathrm{Cu}$, and $0.237 \mathrm{mmol} / \mathrm{g}$ dan for $\mathrm{Zn}$ at $\mathrm{pH}$ 4.o. The suitable isotherm model for adsorption using chicken manure compost is the Langmuir 
adsorption model (Zhang, 2011). The Langmuir isotherm defines that the maximum adsorbent capacity occurs due to a single layer (monolayer) of adsorbate on the surface of the adsorbent. There are four assumptions in this type of isotherm. The first is that the molecule is adsorbed by a static site (where the reaction occurs on the surface of the adsorbent), the second assumption is that each site can hold one adsorbate molecule, the third assumption is that all sites have the same energy and the assumption that all sites have the same energy. The fourth states that there is no interaction between the adsorbed molecule and the surrounding site (Swenson and Stadie, 2019).

Biochar and clamshell are also reported as alternative ways to solve acid mine drainage. Biochar and clamshell produced using low-cost modified reactor using slow pyrolysis. This material reported can significantly reduce $\mathrm{Mn}$ after 40 minutes of time contact. In addition, the clamshell reported that the $\mathrm{pH}$ of acid mine drainage was neutral due to created $\mathrm{Ca}(\mathrm{OH})_{2}$ (Y. G. Wibowo et al., 2020). A recent review reported acid mine drainage treatment's past trend and current outlook. Acid mine drainage bioremediation is carried out in two ways. The first is an active system method using bio-reactor modules and a passive system using aerobic wetlands, anaerobic wetlands, permeable reactive barriers, packed bio-reactors, and algal bioremediation. The bioremediation process in acid mine drainage can be seen in Eq. 10-12.

$\mathrm{SO}_{4}^{2-}+4 \mathrm{H}_{2}+\mathrm{H}^{+} \rightarrow \mathrm{HS}^{-}+4 \mathrm{H}_{2} \mathrm{O}$

Organic matter $(\mathrm{C}, \mathrm{O}$ and $\mathrm{H})+\mathrm{SO}_{4}^{2-} \rightarrow \mathrm{HS}^{-}+\mathrm{HCO}_{3}$

$\mathrm{M}^{2+}+\mathrm{HS}^{-} \rightarrow \mathrm{MS}(\downarrow)+\mathrm{H}+\left(\mathrm{M}^{2+}-\right.$ Metal cation $)$

Another study informs the use of shrimp shells. Shrimp shell samples were taken from Natuna, Indonesia. This study informed that shrimp shells could be processed into adsorbents, reducing Fe and Mn levels by $90 \%$ and $88 \%$, respectively, and increasing $\mathrm{pH}$ from 3.49 to 6.77 . The adsorption capacity of shrimp shells was 17.43 and $3.87 \mathrm{mg} / \mathrm{g}$ by following the Freundlich. isotherm model (Núñez-Gómez et al., 2019). The results of this study are a novelty where shrimp shell material is very rarely found to be used as an adsorbent. The material commonly used as the primary material for adsorbent is the coconut shell because it has good pores and surface area. Although the adsorption capacity of shrimp shells is not large, this study is part of the development of science to find and utilize any waste as an adsorbent. The isotherm model for adsorption using shrimp shells also informs the Freundlich isotherm model. This result is an exciting result to discuss. The Freundlich isotherm describes the type of physical adsorption in which the adsorption occurs in several layers and the bond is not strong. The Freundlich isotherm also assumes that the adsorption site is heterogeneous. Different studies were found to reduce pollutant parameters in acid mine drainage. The utilization of 1,3-benzenediamidoethanethiol dianion has been reported and can reduce pollutant parameters in acid mine drainage $>90 \%$. This research was then developed using acid mine drainage samples from an abandoned mine in Pikeville, Kentucky. The study results then informed that 1,3-benzenediamidoethanethiol dianion was successful in reducing 15 elements in acid mine drainage with different variations in reduction (Matlock et al., 2002). Various studies that have been carried out should complement each other and reduce the shortcomings of other methods. The combination of various methods is expected to continue to be developed so that it can fill the shortcomings of other methods. The combination of precipitation, adsorption and bioremediation methods may significantly remove pollutant parameters in acid mine drainage without producing unknown products. The combination of materials is essential because many reports of surface water is polluted due to mining activities. A study in Gwangyang, South Korea, informed that surface water pollution caused by acid mine drainage had caused health problems caused by $\mathrm{Al}, \mathrm{Fe}$, and low $\mathrm{pH}$ (Kim et al., 2007). There is no information about apple to apple comparision of each acid mine drainage methods. Comparison of different methods in acid mine drainage can be seen in Table 2. 
Table 2. Different methods of acid mine drainage treatment

\begin{tabular}{|c|c|c|c|c|}
\hline No & Method & Materials & $\begin{array}{c}\text { Heavy Metals } \\
\text { (removal percent) }\end{array}$ & Reference \\
\hline 1 & Adsorption & Algae & $\begin{array}{l}\mathrm{Fe} \text { (up to } 100 \%), \mathrm{Cu} \text { (up to } 76 \% \text { ), } \\
\mathrm{Pb} \text { (up to } 78 \% \text { ), }\end{array}$ & (Bwapwa et al., 2017) \\
\hline 2 & Aerobic wetland & No information & $\begin{array}{l}\text { Fe and Mn (no information } \\
\text { about removal percent) }\end{array}$ & (Skousen et al., 2017) \\
\hline 3 & Adsorption & $\begin{array}{l}\text { Chitosan Coated } \\
\text { Coconut Shell } \\
\text { Active Charcoal }\end{array}$ & $\mathrm{Cr}(99 \&)$ & (Lasindrang et al., 2015) \\
\hline 4 & Adsorption & $\begin{array}{l}\text { Peat-Activated } \\
\text { carbon composite }\end{array}$ & $\mathrm{Fe}(79.6 \%)$ & (Rosli et al., 2017) \\
\hline 5 & Adsorption & $\begin{array}{l}\text { activated carbon } \\
\text { made from sago } \\
\text { waste }\end{array}$ & $\begin{array}{l}\mathrm{Hg} \text { (no information about } \\
\text { percent removal, sorption } \\
\text { capacity is } 55.6 \mathrm{mg} / \mathrm{g} \text { ) }\end{array}$ & (Kadirvelu et al., 2004) \\
\hline 6 & Bioremediation & $\begin{array}{l}\text { Lime-dosed, anoxic } \\
\text { limestone drain } \\
\text { and lime free }\end{array}$ & No information & (Whitehead and Prior, 2005) \\
\hline 7 & Bioremerdiation & Bacteria & $\mathrm{Hg}(\mathrm{Up}$ to $80 \mathrm{mg} / \mathrm{L})$ & (Kumari et al., 2020) \\
\hline 8 & Bioremediation & Plant and bacteria & No information & (Rosanti et al., 2020) \\
\hline 9 & Bioremediation & Fungal strains & $\begin{array}{l}\mathrm{Cr}(\mathrm{VI}) \text { (Up to } 100 \%), \mathrm{Cr} \text { (Up to } \\
99.92 \%) \text {, and } \mathrm{Pb}(\mathrm{Up} \text { to } 95.91 \%)\end{array}$ & (Sharma and Malaviya, 2016) \\
\hline 10 & Adsorption & Biochar & $\begin{array}{l}\mathrm{Fe}, \mathrm{Co} \text { (There is no information } \\
\text { about removal percent) }\end{array}$ & (Yang et al., 2020) \\
\hline
\end{tabular}

Various methods have been developed to minimize the formation and damage caused by acid mine drainage contamination which is still ineffective. High costs, difficulties in accessing technology, and low awareness of the importance of environmental sustainability are the causes. It requires concerted efforts, strict regulations, and awareness that acid mine drainage is a significant impact that must be prevented together. All aspects must work together to minimize the formation of acid mine drainage. Mining companies must be willing to spend more money to make good drainage and dewatering systems, make soil with non-potential acid formation, and treat acid mine water formed by various available methods. Acid mine drainage methods will have different levels of efficiency in each region. Mining areas close to swamps will be able to take advantage of passive treatment methods by creating wetland around the acid mine drainage area, while other areas do not have a large area of land. The combination of adsorption, precipitation, and bacterial utilization methods will also be beneficial in accelerating the process of reducing pollutant parameters in acid mine water. The combination of adsorption and precipitation is proven to be more optimal in reducing heavy metals and absorbing other pollutant parameters. This is because precipitation can only precipitate Fe and $\mathrm{Mn}$ and cannot reduce other parameters. Many combined methods are expected to be the best solution in reducing pollutant parameters in acid mine drainage.

\section{Conclusion and Future Research Direction}

Mining activities have caused environmental pollution. Deterioration of water and soil quality has been found in many countries. Pollution caused by acid mine drainage has caused contamination of soil, plants and caused various health problems in humans. Multiple efforts have been made to prevent the formation of acid mine drainage. Creating a non-acid construction by placing rocks that can oxidize 
below the surface has been recommended. Active and passive treatment methods have also been developed to reduce pollutant parameters in acid mine drainage. The active method using alkaline materials is a more effective method when compared to the passive approach, which only relies on natural processes. Quicklime is still the most widely used material to increase the $\mathrm{pH}$ of acid mine drainage by utilizing $\mathrm{Ca}(\mathrm{OH})_{2}$. Increasing the $\mathrm{pH}$ from acidic to neutral conditions are expected to reduce heavy metal levels in acid mine drainage using the precipitation process. Other methods developed to minimize pollutant parameters in acid mine drainage are adsorption and bioremediation. Various studies have developed materials that can reduce pollutant parameters in acid mine drainage. Unfortunately, this method is still not widely applied. Multiple studies reported are still conducting experiments on a laboratory scale and are not ready to be used on an industrial scale. It is hoped that various existing methods can be developed to resolve the acid mine drainage problem. Further research should focus on developing materials that can be combined with active and passive strategies to complement each other and significantly reduce the pollutant parameters of acid mine drainage and not produce unidentified products.

\section{Reference}

Alegbe, M.J., Ayanda, O.S., Ndungu, P., Nechaev, A., Fatoba, O.O., Petrik, L.F. 2019. Physicochemical characteristics of acid mine drainage, simultaneous remediation and use as feedstock for value added products. J. Environ. Chem. Eng. 7.

Aznar-Sánchez, J.A., García-Gómez, J.J., Velasco-Muñoz, J.F., Carretero-Gómez, A., 2018. Mining waste and its sustainable management: Advances in worldwide research. Minerals 8.

Bwapwa, J.K., Jaiyeola, A.T., Chetty, R. 2017. Bioremediation of acid mine drainage using algae strains : A review. South African J. Chem. Eng. 24, 62-70.

Casiot, $\mathrm{C}$ et al., 2009. Hydrological and geochemical control of metals and arsenic in a Mediterranean river contaminated by acid mine drainage (the Amous River, France); preliminary assessment of impacts on fish (Leuciscus cephalus). Appl. Geochemistry 24, 787-799.

Chen, J., Li, X., Jia, W., Shen, S., Deng, S., Ji, B., Chang, J. 2021. Promotion of bioremediation performance in constructed wetland microcosms for acid mine drainage treatment by using organic substrates and supplementing domestic wastewater and plant litter broth. J. Hazard. Mater. 404, 124125.

Demchak, J., Morrow, T., Skousen, J. 2001. Treatment of acid mine drainage by four vertical flow wetlands in Pennsylvania. Geochemistry Explor. Environ. Anal. 1, 71-80.

Genty, T., Bussière, B., Potvin, R., Benzaazoua, M., Zagury, G.J. 2012. Dissolution of calcitic marble and dolomitic rock in high iron concentrated acid mine drainage: Application to anoxic limestone drains. Environ. Earth Sci. 66, 2387-2401.

Gibert, O., Cortina, J.L., de Pablo, J., Ayora, C. 2013. Performance of a field-scale permeable reactive barrier based on organic substrate and zero-valent iron for in situ remediation of acid mine drainage. Environ. Sci. Pollut. Res. 20, 7854-7862.

Järup, L. 2003. Hazards of heavy metal contamination. Br. Med. Bull.

Kadirvelu, K., Kavipriya, M., Karthika, C., Vennilamani, N., Pattabhi, S., 2004. Mercury (II) adsorption by activated carbon made from sago waste. Carbon N. Y. 42, 745-752.

Kefeni, K.K., Msagati, T.A.M., Mamba, B.B. 2017. Acid mine drainage: Prevention, treatment options, and resource recovery: A review. J. Clean. Prod. 151, 475-493.

Kim, Ju Yong et al., 2007. Ecological health assessment and remediation of the stream impacted by acid mine drainage of the Gwangyang mine area. Environ. Monit. Assess. 129, 79-85.

Kumari, S., Amit, Jamwal, R., Mishra, N., Singh, D.K. 2020. Recent developments in environmental mercury bioremediation and its toxicity: A review. Environ. Nanotechnology, Monit. Manag. 13, 100283. 
Lasindrang, M., Suwarno, H., Tandjung, S.D., Kamiso, H.N. 2015. Adsorption Pollution Leather Tanning Industry Wastewater by Chitosan Coated Coconut Shell Active Charcoal. Agric. Agric. Sci. Procedia.

Lasut, M.T., Yasuda, Y. 2010. Distribution and Accumulation of Mercury Derived from Gold Mining in Marine Environment and Its Impact on Residents of Buyat Bay, North Sulawesi , Indonesia. Water Air Soil Pollut. 208, 153-164.

Lewis, A.E. 2010. Review of metal sulphide precipitation. In: Hydrometallurgy. Elsevier B.V., pp. 222234.

Liao, J., Wen, Z., Ru, X., Chen, J., Wu, H., Wei, C. 2016. Distribution and migration of heavy metals in soil and crops affected by acid mine drainage: Public health implications in Guangdong Province, China. Ecotoxicol. Environ. Saf. 124, 460-469.

Luís, A.T., Teixeira, P., Almeida, S.F.P., Ector, L., Matos, J.X., Ferreira Da Silva, E.A. 20o9. Impact of acid mine drainage (AMD) on water quality, stream sediments and periphytic diatom communities in the surrounding streams of aljustrel mining area (Portugal). Water. Air. Soil Pollut. 200, 147-167.

Matlock, M.M., Howerton, B.S., Atwood, D.A. 2002. Chemical precipitation of heavy metals from acid mine drainage. Water Res. 36, 4757-4764.

Mosley, L.M., Willson, P., Hamilton, B., Butler, G., Seaman, R. 2015. The capacity of biochar made from common reeds to neutralise $\mathrm{pH}$ and remove dissolved metals in acid drainage. Environ. Sci. Pollut. Res. 22, 15113-15122.

Motsi, T., Rowson, N.A., Simmons, M.J.H. 2009. Adsorption of heavy metals from acid mine drainage by natural zeolite. Int. J. Miner. Process. 92, 42-48.

Naidoo, S., 2015. An assessment of the impacts of acid mine drainage on socio-economic development in the Witwatersrand: South Africa. Environ. Dev. Sustain. 17, 1045-1063.

Nasir, S., Ibrahim, E., Arief, A.T. 2013. Pendahuluan Air Asam Tambang dan Pengolahannya Sand Filter , Ultrafiltrasi dan Reverse Osmosis 193-200.

Neculita, C.-M., Zagury, G.J., Bussière, B. 2007. Passive Treatment of Acid Mine Drainage in Bioreactors using Sulfate-Reducing Bacteria. J. Environ. Qual. 36, 1-16.

Núñez-Gómez, D., Rodrigues, C., Lapolli, F.R., Lobo-Recio, M.Á. 2019. Adsorption of heavy metals from coal acid mine drainage by shrimp shell waste: Isotherm and continuous-flow studies. J. Environ. Chem. Eng. 7.

Poedjiratrajoe, E. 2012. Upaya penurunan kadar logam berat arsen(as) yang berasal dari air rembesan waste rock tambang pt. newmont minahasa raya melalui metode fitoremediasi. Pros. Semin. Air Asam Tambang di Indones. Ke 439-46.

Qureshi, A., Maurice, C., Öhlander, B. 2016. Potential of coal mine waste rock for generating acid mine drainage. J. Geochemical Explor. 160, 44-54.

Rakotonimaro, T. V., Neculita, C.M., Bussière, B., Benzaazoua, M., Zagury, G.J. 2017. Recovery and reuse of sludge from active and passive treatment of mine drainage-impacted waters: a review. Environ. Sci. Pollut. Res. 24, 73-91.

Rambabu, K., Banat, F., Pham, Q.M., Ho, S.-H., Ren, N.-Q., Show, P.L. 2020. Biological remediation of acid mine drainage: Review of past trends and current outlook. Environ. Sci. Ecotechnology 2, 100024.

Rosanti, D., Wibowo, Y.G., Safri, M., Maryani, A.T. 2020. Bioremediations Technologies on Wastewater Treatment: Opportunities, Challenges and Economic Perspective. Sainmatika J. Ilm. Mat. dan Ilmu Pengetah. Alam 17, 142-156.

Rosli, M.A et al., 2017. The effectiveness of Peat-AC composite adsorbent in removing color and Fe from landfill leachate. Int. J. Integr. Eng. 9, 35-38.

RoyChowdhury, A., Sarkar, D., Datta, R. 2015. Remediation of Acid Mine Drainage-Impacted Water. Curr. Pollut. Reports 1, 131-141.

Sabina, R.O., Santos, E.S., Abreu, M.M. 2019. Accumulation of Mn and Fe in aromatic plant species from 
the abandoned Rosalgar Mine and their potential risk to human health. Appl. Geochemistry 104, 42-50.

Said, N.I. 2014. Teknologi pengolahan air asam tambang batubara "Alternatif Pemilihan Teknologi ." JAI 7, 119-138.

Sari, D.K., Kusniawati, E., Srimardani, R. 2020. Peningkatan Kualitas Air Asam Tambang Menggunakan Zeolit Dan Bakteri Sebagai Media Adsorpsi Dengan Metode Sedimentasi Secara Anaerob Di Pt Bukit Asam, Tbk. Tanjung Enim, Sumatera Selatan. J. Tek. Patra Akad. 11, 1-9.

Sharma, S., Malaviya, P. 2016. Bioremediation of tannery wastewater by chromium resistant novel fungal consortium. Ecol. Eng. 91, 419-425.

Sheoran, A.S., Sheoran, V. 2006. Heavy metal removal mechanism of acid mine drainage in wetlands: A critical review. Miner. Eng. 19, 105-116.

Skousen, J et al., 2017. Review of Passive Systems for Acid Mine Drainage Treatment. Mine Water Environ. 36, 133-153.

Skousen, J.G., Ziemkiewicz, P.F., McDonald, L.M. 2019. Acid mine drainage formation, control and treatment: Approaches and strategies. Extr. Ind. Soc. 6, 241-249.

Swenson, H., Stadie, N.P. 2019. Langmuir's Theory of Adsorption: A Centennial Review. Langmuir 35 , 5409-5426.

Tabelin, C.B., Seno, K., Hiroyoshi, N., Ito, M., Li, X., Park, I., Jeon, S. 2018. A review of recent strategies for acid mine drainage prevention and mine tailings recycling. Chemosphere 219, 588-606.

To, T.B., Nordstrom, D.K., Cunningham, K.M., Ball, J.W., Mccleskey, R.B. 1999. New method for the direct determination of dissolved $\mathrm{Fe}(\mathrm{III})$ concentration in acid mine waters. Environ. Sci. Technol. $33,807-813$.

Tomiyama, S., Igarashi, T., Tabelin, C.B., Tangviroon, P., Ii, H. 2019. Acid mine drainage sources and hydrogeochemistry at the Yatani mine, Yamagata, Japan: A geochemical and isotopic study. J. Contam. Hydrol. 225, 103502.

Tutu, H., McCarthy, T.S., Cukrowska, E. 2008. The chemical characteristics of acid mine drainage with particular reference to sources, distribution and remediation: The Witwatersrand Basin, South Africa as a case study. Appl. Geochemistry 23, 3666-3684.

Wei, X., Zhang, S., Shimko, J., Dengler, R.W. 2019. Mine drainage: Treatment technologies and rare earth elements. Water Environ. Res. 91, 1061-1068.

Whitehead, P.G., Prior, H. 2005. Bioremediation of acid mine drainage: An introduction to the Wheal Jane wetlands project. Sci. Total Environ. 338, 15-21.

Wibowo, Y. G., Sudibyo, Muhammad, D., Naswir, M., Muljadi, B.P. 2020. Low-cost modified reactor to produce biochar and clamshell as alternative materials from acid mine drainage problem solving. IOP Conf. Ser. Earth Environ. Sci. 483.

Wibowo, Yudha Gusti, Sudibyo, Rosarina, D. 2020. Adsorption of metals ion with biochar derived from biomass waste with fixed column. Int. J. Acad. Multidiscip. Res. 4, 21-27.

Wibowo, Y.G., Syarifuddin, H. 2018. Rancangan Dimensi Pada Tambang Terbuka Sebagai Upaya Pencegahan Kerusakan Lingkungan Yang Diakibat Oleh Air Asam Tambang. In: Semnas SINTA FT UNILA. pp. 49-53.

Wood, T.A., Murray, K.R., Burgess, J.G. 20o1. Ferrous sulphate oxidation using Thiobacillus ferrooxidans cells immobilised on sand for the purpose of treating acid mine-drainage. Appl. Microbiol. Biotechnol. 56, 560-565.

Yang, B., et al., 2020. The use of biochar for controlling acid mine drainage through the inhibition of chalcopyrite biodissolution. Sci. Total Environ. 737, 139485.

Zhang, M. 2011. Adsorption study of $\mathrm{Pb}(\mathrm{II}), \mathrm{Cu}(\mathrm{II})$ and $\mathrm{Zn}(\mathrm{II})$ from simulated acid mine drainage using dairy manure compost. Chem. Eng. J. 172, 361-368. 